\title{
Pengembangan perangkat pembelajaran geometri berbasis kecerdasan majemuk siswa SMP kelas VIII
}

\author{
Pasttita Ayu Laksmiwati ${ }^{*}$ (D), Endah Retnowati ${ }^{2}$ \\ ${ }^{1}$ SEAMEO Regional Centre for Qitep in Mathematics, Indonesia \\ ${ }^{2}$ Department of Mathematics Education, Universitas Negeri Yogyakarta, Indonesia \\ *Corresponding Author. E-mail: pasttitalaks@gmail.com
}

\begin{tabular}{ll}
\hline \multicolumn{1}{c}{ ARTICLE INFO } & \multicolumn{1}{c}{ ABSTRACT } \\
\hline Article History: & Penelitian ini bertujuan untuk menghasilkan dan mendeskripsikan proses pengembangan dan \\
Received: 28 May 2019 & kualitas perangkat pembelajaran geometri berbasis konsep kecerdasan majemuk dari Howard \\
Revised: 15 June 2019 & Gardner. Penelitian pengembangan ini mengadopsi model pengembangan Plomp terdiri dari \\
Accepted: 28 June 2019 & tahapan penelitian awal, pengembangan, dan evaluasi. Perangkat pembelajaran geometri \\
& yang dikembangkan meliputi rencana pelaksanaan pembelajaran, buku, dan lembar kerja \\
& siswa untuk materi Geometri Kelas VIII Semester 2 berbasis kecerdasan majemuk. Kualitas hasil \\
Keywords: & pengembangan ditinjau dari tiga aspek yaitu kevalidan, keefektifan, dan kepraktisan. Berdasar- \\
Perangkat pembelajaran & kan penilaian kualitas kevalidan, diperoleh bahwa perangkat mendapatkan kriteria sangat baik. \\
Kecerdasan majemuk & Hal ini terjadi karena perangkat yang dikembangkan sesuai dengan indikator pembelajaran dan \\
Prestasi belajar & prinsip pembelajaran berbasis kecerdasan majemuk. Aspek keefektifan didasarkan pada \\
Self-esteem & pencapaian prestasi belajar siswa dan self-esteem. Keefektifan produk berdasarkan prestasi \\
Learning kit & belajar diperoleh dari persentase banyaknya siswa yang mencapai Kriteria Ketuntasan Minimal \\
multiple intellegences & (KKM) sebesar 75, dimana diketahui terdapat 82,05\% siswa mencapai KKM. Keefektifan juga \\
& ditinjau dari self-esteem siswa, dimana setelah pembelajaran self-esteem siswa berada pada \\
& level tinggi. Sementara itu, respon siswa dan guru terhadap kepraktisan penggunaan perang- \\
& kat masing-masing adalah sebesar 4,175 (diklasifikasikan praktis) dan 4,625 (diklasifikasikan \\
& sangat praktis). Berdasarkan hasil observasi terhadap pembelajaran diketahui bahwa keter- \\
& laksanaan pembelajaran adalah sebesar 96,82\% (di kelas A) dan 97,61\% (di kelas B), sehingga \\
& pembelajaran terlaksana dengan baik sesuai dengan rencana. Oleh karena itu, berdasarkan \\
& hasil penelitian tersebut, dapat disimpulkan bahwa perangkat pembelajaran geometri yang \\
& dikembangkan layak untuk digunakan. \\
\hline &
\end{tabular}

This study aimed to produce and describe the development process and quality of geometry learning kit based on multiple intelligences from Howard Gardner. This study adopted Plomp's model of research design, consisting of preliminary research, developing, and evaluation. As a result, this research was developed learning kit, which includes lesson plans, a handbook, and worksheets of geometry for 8 th graders 2 nd semester. The quality of the developed instructions was described by its validity, effectiveness, and practicality aspect. The effectiveness of the product based on learning achievement was obtained from the percentage of the number of students who reach the Minimum Completeness Criteria (MCC), which was 75, where it was known that there were $82.05 \%$ of students achieving the MCC. The other effectiveness result can be seen from students' self-esteem, after following the learning designed, it has a mean score with high classification. The students' and teacher's response was 4.175 (can be categorized practical) and 4.625 (categorized very practical), respectively. The result of learning observations showed that the percentage of the implementation learning was $96.82 \%$ (class $A$ ) and $97.61 \%$ (class B), so it can be seen that the learning process was taking place. Thus, the result of the study shows the learning kit was appropriate to be used.

\section{How to Cite:}

Laksmiwati, P. A., \& Retnowati, E. (2019). Pengembangan perangkat pembelajaran geometri berbasis kecerdasan majemuk siswa SMP kelas VIII. PYTHAGORAS: Jurnal Pendidikan Matematika, 14(1), 1-11. doi: https://doi.org/10.21831/pg.v14i1.26591 


\section{PENDAHULUAN}

Secara umum pendidikan bertujuan untuk mempersiapkan individu dalam menghadapi tantangan kehidupan. Melalui pendidikan potensi individu dikembangkan untuk mampu menghadapi setiap masalah dan perubahan dalam kehidupan. Oleh karena itu, pendidikan penting untuk mendapat perhatian termasuk perangkat pembelajaran di sekolah. Matematika adalah salah satu pelajaran yang wajib dipelajari di sekolah. NCTM (2000, pp.16-17) menyatakan bahwa dalam pembelajaran matematika di sekolah bertujuan untuk meningkatkan kemampuan siswa dalam memahami matematika, kemampuan siswa dalam menyelesaikan masalah matematika, kepercayaan diri siswa, sikap dan tindakan siswa terhadap matematika. Pembelajaran matematika berhubungan dengan kemampuan dan ketrampilan menyelesaikan masalah matematika. Pembelajaran matematika di sekolah erat kaitannya dengan dimensi kognitif yang dimiliki oleh siswa. Pembelajaran yang efektif memberi kesempatan siswa untuk terlibat langsung dalam proses belajar dan menyelesaikan masalah sehingga memfasilitasi siswa untuk untuk benar-benar memahami materi. Agar pembelajaran matematika efektif dibutuhkan pemahaman mengenai pengetahuan siswa, kebutuhan untuk belajar, tantangan, dan dukungan untuk belajar dengan baik.

Pembelajaran matematika di sekolah harus bisa memperhatikan karakteristik siswa agar dapat memfasilitasi siswa untuk belajar dengan baik. Berdasarkan empat tahap perkembangan kognitif Piaget, siswa SMP telah mencapai tahap operasional formal (lebih dari 11 tahun) yang mana siswa dianggap mampu berpikir abstrak, idealis dan logis (Santrock, 2011, p.174). Karakteristik berpikir abstrak tersebut menunjukkan mereka memiliki kemampuan pemecahan masalah secara verbal (the adolescent's verbal problem-solving ability). Siswa dengan kemampuan berpikir abstrak dapat menyelesaikan masalah matematika melalui presentasi verbal (verbal presentation) permasalahan tanpa visualisasi konkret. Indikasi lain dari karakteristik berpikir abstrak adalah meningkatnya kecenderungan siswa untuk memikirkan ide-ide (to think about thought).

Kecerdasan merupakan kemampuan seseorang untuk menggunakan pengetahuan. Selaras dengan hal tersebut, kemampuan dapat didefinisikan sebagai kompetensi kognitif atau metakognitif yang dapat dikembangkan melalui latihan (McCombs \& Pope, 1994, p.16; Reynolds \& Miller, 2003, p.64). Selanjutnya, Phye (1997, p.403) menambahkan bahwa penilaian dari kemampuan siswa merupakan representasi dari kecenderungan pertumbuhan untuk terlibat secara langsung dan aktif dalam proses pembelajaran. Jadi, melalui keterlibatan langsung dalam pembelajaran kemampuan dapat dikembangkan. Teori mengenai kecerdasan majemuk pertama kali dikembangkan oleh Howard Gardner yang mengemukakan bahwa setidaknya terdapat delapan kecerdasan dasar manusia yang disebut teori kecerdasan majemuk. Namunpada tahun 1999, Gardner mengembangkan kecerdasan menjadi sembilan dengan kecerdasan eksistensial sebagai kecerdasan yang ke sembilan. Kecerdasan majemuk mencakup 8 jenis kecerdasan yaitu linguistik, logis-matematis, spasial, kinestetik-tubuh, musikal, interpersonal, intrapersonal, dan naturalis (Armstrong, 2009, pp.5-7). Kecerdasan ke sembilan yang melengkapi kecerdasan majemuk menjadi sembilan adalah kecerdasan eksistensial (Campbell \& Campbell, 1999, p.5).

Berdasarkan keberagaman kecerdasan yang dimiliki siswa, tidak berarti guru harus melakukan pembelajaran yang bersifat individual karena kecerdasan siswa juga berkembang ketika siswa berinteraksi dengan siswa yang lain. Dalam setiap pembelajaran matematika, guru perlu menggunakan aktivitas pembelajaran yang lebih bervariasi sehingga memfasilitasi berbagai kecerdasan majemuk siswa. Keberagaman kecerdasan siswa berperan menjadi ide dasar bagi guru untuk mengembangkan metode pembelajaran dan perangkat pembelajaran klasikal (Widjajanti, 2012, p.2). Pengembangan perangkat pembelajaran matematika yang dapat memfasilitasi kecerdasan majemuk siswa diperlukan sebagai rujukan bagi guru dalam pembelajaran matematika di sekolah.

Beralih ke prestasi belajar, Robert (2009, p.9) menjelaskan bahwa prestasi belajar merupakan indikator pencapaian pengetahuan, pemahaman, dan keterampilan. Capaian ini dapat diukur melalui suatu tes. Prestasi belajar matematika diraih dalam jangka waktu tertentu, setelah siswa menyelesaikan pembelajaran untuk kompetensi tertentu dan menjadi fokus dan harapan utama yang dicapai setiap satuan pendidikan (Muslimin, 2012, p.382; Lovat, Dally, Clement, \& Toomey, 2011, p.6). Dengan kata lain, prestasi belajar dianggap sebagai ukuran penting pencapaian hasil belajar siswa. Akan tetapi, Dehyadegary, Divsalar, Shahsavari, Nekouei, dan Sadr (2012, p.823) mengungkapkan bahwa rendahnya prestasi belajar adalah masalah yang dihadapi oleh sebagian besar negara di dunia, terutama negara berkembang untuk setiap jenjang pendidikan.

Salah satu penelitian survei yang dilakukan secara internasional untuk mengetahui pencapaian prestasi siswa SMP dalam belajar matematika adalah TIMSS (Trends in International Matemathics and Science Study). Menurut 
TIMSS rata-rata prestasi matematika yang diraih siswa SMP Indonesia pada tahun 2011 mengalami penurunan dibandingkan tahun 2007 dari 397 menjadi 386 (Mullis, Martin, \& Foy, 2008, p.35; Mullis, Martin, Foy, \& Arora, 2012, p.42). Indonesia berada pada peringkat 36 dari 49 negara pada tahun 2007 dan berada pada peringkat 38 dari 42 negara pada tahun 2011. Peringkat rata-rata prestasi matematika Indonesia berada di bawah negaranegara seperti Thailand, Malaysia dan Singapura. Hasil studi dari TIMSS tersebut memperlihatkan prestasi belajar matematika siswa Indonesia masih perlu untuk ditingkatkan. Prestasi belajar matematika di Indonesia masih rendah dapat dilihat dari hasil Ujian Nasional (UN) yang menunjukkan kecenderungan penurunan, khususnya di bidang Geometri. Sebagai contoh di Kabupaten Wonosobo, Jawa Tengah pada materi memahami bangun datar, bangun ruang, sudut, serta menggunakannya dalam pemecahan masalah. Pada tahun 2012 siswa di daerah ini mencapai penguasaan hanya sebesar 52,13\% dan menurun sebesar 3,74 \% menjadi 48,39\% pada tahun 2013 (BSNP, 2012; BSNP, 2013).

Ada berbagai faktor yang dapat menyebabkan rendahnya prestasi belajar matematika, diantaranya adalah rendahnya hubungan interpersonal, kurangnya motivasi, dan kesempatan belajar yang kurang di dalam pembelajaran di kelas (McKinley, 2010, p.2). Oleh karena itu, dalam usaha mengembangkan prestasi belajar perlu adanya interaksi antara siswa dalam pembelajaran matematika, misalnya kerja sama dan diskusi dalam kelompok supaya antar siswa bisa terlibat aktif dalam pembelajaran. Brownlie, Renihan, Ladyman, Sumanik, MacRae, dan Wickstorm (2003, p.12) menyarankan untuk mengembangkan prestasi belajar siswa dengan cara melibatkan pengalaman langsung dan melibatkan siswa aktif dalam belajar.

Beralih ke ranah afektif, pembelajaran matematika diharapkan dapat mengembangkan kemampuan afektif seperti sikap matematika dan self-esteem siswa (Popham, 1995, p.179). Kemampuan afektif siswa seperti selfesteem juga dapat mempengaruhi kemampuan kognitif siswa. Hal ini sesuai dengan pendapat yang disampaikan oleh Muijs dan Reynolds (2011, p.185) yang menyatakan bahwa meningkatkan self-esteem siswa dapat meningkatkan prestasi belajar mereka. Akan tetapi, pada kenyataan yang ditemui di lapangan, fakta dan harapan yang ada ternyata masih belum sesuai. Sebagian besar siswa masih memiliki kecenderungan sikap negatif terhadap matematika. Selain itu, siswa juga masih cenderung menganggap matematika sebagai pelajaran yang menakutkan dan membosankan (Leonard \& Supardi, 2010, p.342; Ignacio, Nieto, \& Barona, 2006, p.17).

Muijs dan Reynolds (2011, p.179) menyatakan apabila seseorang memiliki self-esteem yang rendah maka mereka akan bersikap negatif selama pembelajaran matematika. Salah satu penyebab yang mungkin mengakibatkan self-esteem rendah adalah lingkungan pembelajaran di kelas yang kurang tepat. Maksudnya pembelajaran tersebut kurang melibatkan siswa secara aktif dalam pembelajaran. Oleh karena itu, dalam pembelajaran di kelas siswa harus diposisikan sebagai pembelajar aktif yang berpusat pada siswa dan sesuai dengan paradigma konstruktivisme. Selain itu menurut Santrock (2011, p.551) penilaian yang terlalu sulit juga dapat menyebabkan rendahnya self-esteem siswa. Penilaian diharapkan dapat mengetahui perkembangan siswa dalam belajar. Penilaian siswa yang terlalu sulit membuat siswa merasa tertekan dan terkadang menganggap dirinya tidak mampu. Hal tersebut yang mungkin dapat menyebabkan rendahnya self-esteem siswa.

Siswa SMP yang mulai mengalami pubertas biasanya mulai memiliki masalah dengan self-esteem yang menurun. Hal ini sesuai dengan pendapat yang disampaikan oleh Slavin (2006, p.88), bahwa self-esteem siswa tersebut mengalami penurunan, terutama pada siswa perempuan. Pada umumnya, remaja putri memiliki selfesteem yang lebih rendah daripada remaja putra. Selanjutnya, peran lingkungan sosial dan penerimaan yang akan menguatkan self-esteem yang mereka miliki. Arends (2012, p.145) self-esteem yang dimiliki oleh siswa berhubungan dengan perasaan yang mereka miliki mengenai kompetensi, hubungan dan pengaruh dirinya. Misalnya, seorang anak yang tidak memiliki banyak teman akan merasa ditinggalkan dan biasanya memiliki self-esteem yang rendah. Oleh karena itu guru perlu untuk membangun komunitas di dalam kelas, dimana setiap siswa akan menemukan tempat dimana mereka merasa didukung dalam pembelajaran. Brown, Dutton, dan Cook (2001, p.616) menyatakan bahwa, "Self-esteem is most commonly used to refer to the way people characteristically feel about themselves". Apabila dimaknai, berdasarkan pendapat tersebut diketahui bahwa self-esteem berhubungan dengan evaluasi diri, bagaimana seseorang merasakan karakter yang dimiliki, dan bagaimana seseorang menilai kemampuan dirinya.

Proses pembelajaran matematika di sekolah diharapkan bertujuan untuk memfasilitasi kecerdasan majemuk. Kesadaran akan konsep bahwa setiap siswa memiliki perbedaan individu penting untuk dipahami karena tiap individu memiliki potensi yang berbeda. Perbedaan individu ini salah satunya diindikasikan dalam kecerdasan majemuk (multiple intelligences). Kecerdasan majemuk merupakan salah satu potensi yang dimiliki oleh siswa dan 
berpengaruh terhadap prestasi belajar siswa dan self-esteem. Adapun perangkat pembelajaran yang memfasilitasi dan mengakomodasi kecerdasan majemuk adalah salah satu upaya untuk mendukung keberhasilan belajar mereka. Oleh karena belum banyak perangkat pembelajaran matematika berbasis kecerdasan majemuk yang dikembangkan, maka perlu adanya penelitian untuk mengembangkan perangkat pembelajaran matematika yang berorientasi pada prestasi belajar dan self-esteem terutama pada pembelajaran geometri. Berdasarkan hasil pengamatan yang dilakukan oleh peneliti dan guru di SMP Negeri 3 Selomerto, Wonosobo, Jawa Tengah, perangkat pembelajaran berbasis kecerdasan majemuk sangat diperlukan karena belum terdapat pengembangan perangkat tersebut di Wonosobo. Oleh karena itu, penelitian ini bertujuan untuk untuk menghasilkan dan mendeskripsikan proses pengembangan dan kualitas perangkat pembelajaran geometri berbasis konsep kecerdasan majemuk dari Howard Gardner.

\section{METODE}

Jenis penelitian dalam penelitian ini adalah penelitian desain untuk mengembangkan teori pembelajaran lokal (local instruction theory). Gravemeijer (2004, p.108) menyatakan bahwa inti dari jenis penelitian ini adalah pengembangan serangkaian pembelajaran yang juga mencakup perangkat pembelajaran. Penelitian ini merupakan penelitian kualitatif yang dilihat dari tiga perspektif yaitu kevalidan, kepraktisan, dan keefektifan. Lebih khusus, penelitian ini bertujuan untuk mengembangkan perangkat pembelajaran geometri berbasis kecerdasan majemuk yang memenuhi kualitas valid, praktis, dan efektif (Nieveen, 1999, p.126). Model pengembangan yang digunakan dalam penelitian pengembangan pendidikan menurut $\operatorname{Plomp}(2013, \mathrm{p} .19)$ mencakup tiga tahapan, yaitu penelitian awal, pengembangan, dan evaluasi yang diilustrasikan pada Gambar 1.

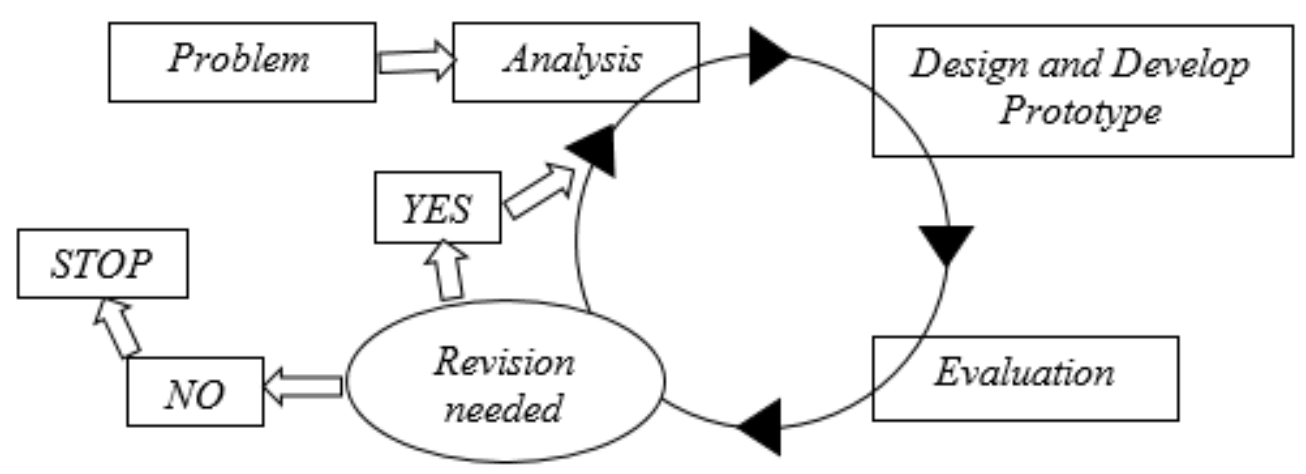

Gambar 1. Iterations of Systematic Design Cycles dari Model Pengembangan Plomp

Prosedur penelitian yang digunakan mencakup beberapa tiga tahapan. Pertama, tahapan penelitian awal (preliminary research), dalam tahapan penelitian awal ini dilakukan analisis kebutuhan dan analisis situasi. Hal yang menjadi unsur penting dalam tahapan ini adalah pengumpulan dan analisis informasi, mendefinisikan masalah, dan merencanakan kegiatan lanjutan berdasarkan masalah yang ditemukan. Peneliti melakukan observasi sebagai bentuk realisasi tahapan ini. Kemudian, ditentukan produk yang akan dikembangkan. Kedua, tahapan pengembangan (development or prototyping phase), dalam kegiatan yang dilakukan dalam tahapan yang kedua ini adalah mendesain solusi dari masalah yang telah didefinisikan dalam penelitian awal. Hasil dalam tahapan ini berupa dokumen sebagai bentuk solusi dari masalah yang ditemukan di tahapan penelitian awal. Selanjutnya, dalam tahapan ini dibuat desain versi pertama yang disebut dengan prototype. Dalam tahapan ini dirumuskan alternatif desain yang akan dikembangkan terkait dengan permasalahan tersebut. Selanjutnya proses pengembangan produk juga dilakukan pada tahapan ini. Tahapan yang ketiga adalah assessment phase dimana dalam tahapan ini dilakukan implementasi dan evaluasi yang bertujuan untuk memperbaiki produk yang dikembangkan. Implementasi yang dilakukan berupa uji coba produk kepada siswa kelas VIII. Uji coba produk dilaksanakan pada bulan April-Juni 2015 di SMP Negeri 3 Selomerto, Wonosobo, Jawa Tengah. Subjek uji coba dalam penelitian ini adalah 50 siswa kelas VIII SMP Negeri 3 Selomerto Tahun Ajaran 2014/2015 sebanyak 2 kelas yaitu kelas A dan kelas B. Model pengembangan pendidikan menurut Plomp dipilih karena model ini dianggap relatif sederhana dan praktis. Adapun prosedur pengembangan produk pada penelitian ini disajikan melalui bagan pada Gambar 2. 


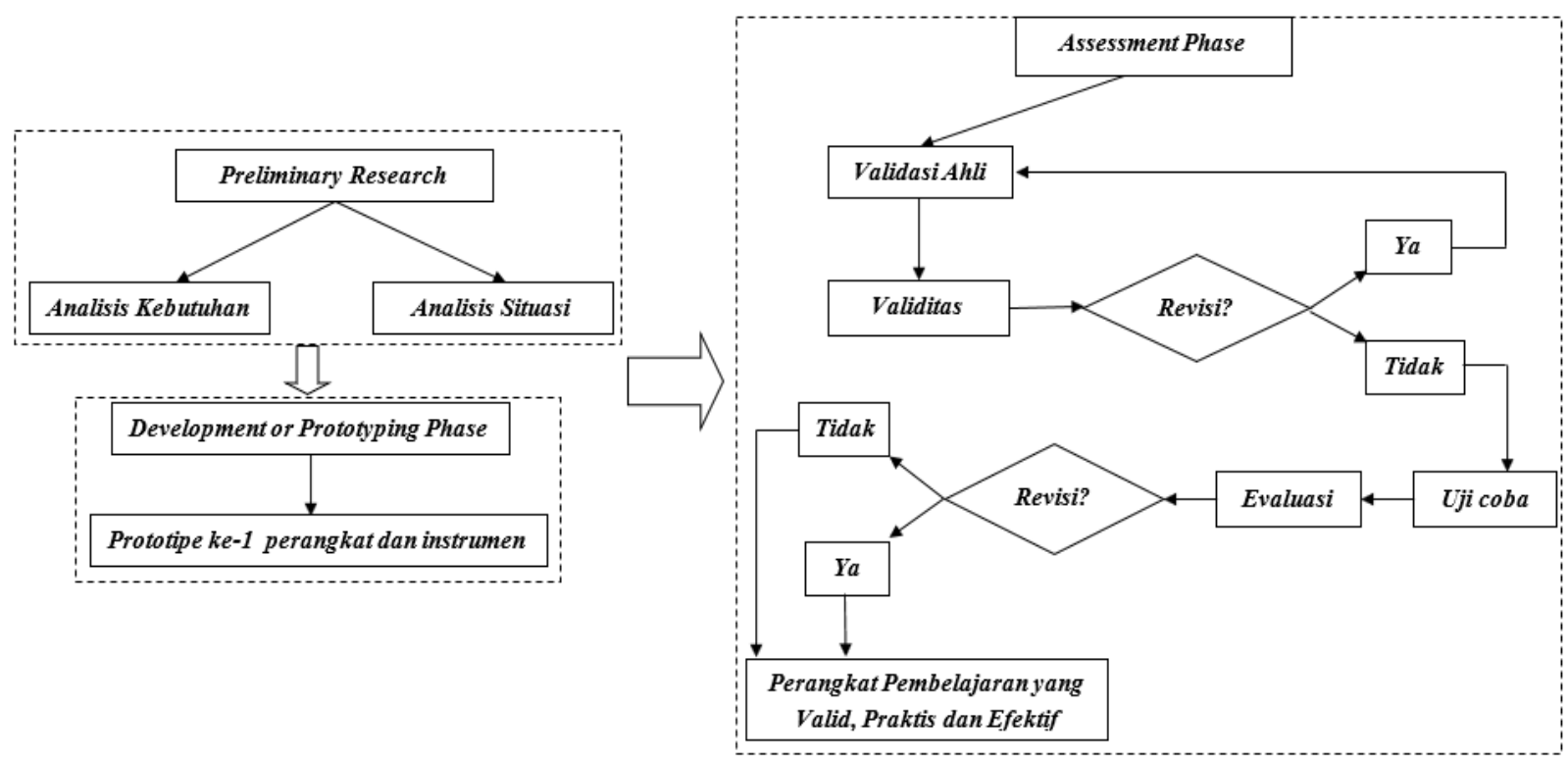

Gambar 2. Prosedur Pengembangan Perangkat Pembelajaran Berbasis Kecerdasan Majemuk

Proses analisis data dalam penelitian ini mencakup penilaian kevalidan, keefektifan, dan kepraktisan dari perangkat pembelajaran yang dikembangkan berdasarkan penilaian dari para ahli, digunakan pedoman menurut Widoyoko (2012, p.110) dan Azwar (2007, p.163) untuk menentukan klasifikasi interpretasi ke dalam skala 5 seperti disajikan pada Tabel 1, Tabel 2, Tabel 3, dan Tabel 4.

Tabel 1. Klasifikasi Penilaian Kualitas Kevalidan

\begin{tabular}{ll}
\hline Interval Rerata Skor & Klasifikasi \\
\hline $4,2<\bar{x} \leq 5$ & Sangat Baik \\
$3,4<\bar{x} \leq 4,2$ & Baik \\
$2,6<\bar{x} \leq 3,4$ & Cukup Baik \\
$1,8<\bar{x} \leq 2,6$ & Tidak Baik \\
$1,0 \leq \bar{x}<1,8$ & Sangat Tidak Baik \\
\hline
\end{tabular}

Kualitas perangkat pembelajaran dianggap valid dan layak sebagai perangkat pembelajaran apabila memenuhi klasifikasi baik atau $\bar{x}>3,4$.

Tabel 2. Klasifikasi Penilaian Kualitas Keefektifan

\begin{tabular}{lll}
\hline & \multicolumn{1}{c}{ Interval } & \multicolumn{1}{c}{ Klasifikasi } \\
\hline Persentase KKM Prestasi Belajar & $80 \%<\mathrm{t} \leq 100 \%$ & Sangat tinggi \\
& $60 \%<\mathrm{t} \leq 80 \%$ & Tinggi \\
& $40 \%<\mathrm{t} \leq 60 \%$ & Sedang \\
& $20 \%<\mathrm{t} \leq 40 \%$ & Rendah \\
& $0 \% \leq \mathrm{t}<20 \%$ & Sangat rendah \\
\hline Skor Self-esteem & $144<\mathrm{x} \leq 168$ & Sangat tinggi \\
& $120<\mathrm{x} \leq 144$ & Tinggi \\
$96<\mathrm{x} \leq 120$ & Sedang \\
& $72<\mathrm{x} \leq 96$ & Rendah \\
$36 \leq \mathrm{x} \leq 72$ & Sangat rendah \\
\hline
\end{tabular}

Penilaian kualitatif dari aspek keefektifan menggunakan pedoman pada Tabel 2. Kualitas perangkat pembelajaran dianggap efektif apabila persentase KKM siswa mencapai klasifikasi tinggi atau $t>60 \%$ skor self-esteem siswa minimal mencapai klasifikasi tinggi atau $\mathrm{x}>120$. Pada penilaian kualitas kepraktisan akan digunakan pedoman penilaian yang disajikan pada Tabel 3. Kualitas perangkat pembelajaran dianggap memenuhi kualitas kepraktisan sebagai perangkat pembelajaran apabila memiliki klasifikasi praktis atau $\bar{x}>3,4$. 
Tabel 3. Klasifikasi Kepraktisan Angket Respon

\begin{tabular}{ll}
\hline Interval Rerata Skor & Klasifikasi \\
\hline $4,2<\bar{x} \leq 5$ & Sangat Praktis \\
$3,4<\bar{x} \leq 4,2$ & Praktis \\
$2,6<\bar{x} \leq 3,4$ & Cukup Praktis \\
$1,8<\bar{x} \leq 2,6$ & Tidak Praktis \\
$1,0 \leq \bar{x}<1,8$ & Sangat Tidak Praktis \\
\hline
\end{tabular}

Selanjutnya digunakan klasifikasi secara kualitatif yang digunakan untuk menentukan persentase keterlaksanaan pembelajaran seperti disajikan pada Tabel 4 .

Tabel 4. Klasifikasi Kualitatif Keterlaksanaan Pembelajaran

\begin{tabular}{ll}
\hline Interval & Klasifikasi \\
\hline $80 \%<\mathrm{t} \leq 100 \%$ & Sangat Baik \\
$60 \%<\mathrm{t} \leq 80 \%$ & Baik \\
$40 \%<\mathrm{t} \leq 60 \%$ & Cukup Baik \\
$20 \%<\mathrm{t} \leq 40 \%$ & Tidak Baik \\
$\mathrm{t} \leq 20 \%$ & Sangat Tidak Baik \\
\hline
\end{tabular}

Berdasarkan hasil klasifikasi keterlaksanaan pembelajaran kualitas perangkat pembelajaran dianggap praktis apabila memenuhi klasifikasi baik atau $t>60 \%$.

Adapun produk hasil pengembangan dalam penelitian ini adalah perangkat pembelajaran yang mencakup rencana pelaksanaan pembelajaran (RPP), buku, dan lembar kerja siswa untuk materi Geometri Kelas VIII Semester 2 berbasis kecerdasan majemuk yang berorientasi pada prestasi belajar dan self-esteem siswa.

\section{HASIL DAN PEMBAHASAN}

Belajar merupakan suatu aktivitas mental atau psikis yang merupakan proses aktif dalam membangun pengetahuan, berlangsung dalam interaksi individu dengan sumber belajarnya, yang menghasilkan sejumlah perubahan (Winkel, 2004, p.53; Hewitt, 2008, p.35). Perangkat pembelajaran yang dikembangkan dalam penelitian ini sesuai dengan pendapat para ahli tersebut. Melalui perangkat pembelajaran geometri ini, siswa melakukan aktivitas membangun pengetahuan mereka secara aktif melalui lembar kegiatan siswa (LKS).

Proses pembelajaran matematika dengan perangkat pembelajaran yang dikembangkan merupakan pembelajaran yang mengajak siswa aktif untuk terlibat dalam proses belajar. Berdasarkan keberagaman kecerdasan yang dimiliki siswa, tidak berarti guru harus melakukan pembelajaran yang bersifat individual. Keberagaman kecerdasan siswa berperan menjadi modal bagi guru untuk mengembangkan metode pembelajaran yang dapat memfasilitasi siswa melalui kecerdasan majemuk yang mereka miliki (Widjajanti, 2012, p.2). Dalam setiap pembelajaran matematika, guru perlu menggunakan strategi pembelajaran yang lebih bervariatif untuk memfasilitasi kecerdasan majemuk siswa. Dalam proses belajar mengajar, guru juga selalu mengenalkan ide bahwa setiap siswa cerdas dan tentunya kecerdasan siswa satu sama lain tidaklah sama. Setiap siswa unik dengan kecerdasan yang dimiliki, sehingga siswa belajar bahwa setiap diri mereka cerdas dengan keunikan mereka masing-masing.

Guru mengawali pembelajaran dengan memberikan motivasi dan mempersilahkan untuk bekerja kelompok. Siswa dalam proses pembelajaran menggunakan perangkat pembelajaran yang ada dan memanfaatkannya untuk belajar. Keunikan dari perangkat pembelajaran ini tentunya adalah kegiatan pembelajaran yang bervariasi dengan tujuan memfasilitasi kecerdasan majemuk siswa. Aktivitas-aktivitas yang dirancang pada LKS juga bervariasi dan bertujuan memfasilitasi kecerdasan majemuk siswa. Siswa selalu diberikan motivasi bahwa mereka semua cerdas dan unik, serta memiliki kelebihan masing-masing. Hal ini juga bertujuan untuk memberikan kontribusi positif pada self-esteem siswa. Kegiatan yang dilakukan dalam pembelajaran mencakup variasi kegiatan contohnya presentasi, membaca puisi, kerja kelompok dan sebagainya. Siswa belajar dari berbagai sumber belajar yang tersedia. Siswa mengamati dan melakukan investigasi, selain itu siswa juga mengikuti permainan. Kegiatan pembelajaran berlangsung dengan baik. Siswa aktif bertanya dan mengerjakan tugas yang diberikan oleh guru.

Produk hasil pengembangan terdiri dari perangkat pembelajaran geometri yang meliputi Rencana Pelaksanaan Pembelajaran, Buku Geometri, dan Lembar Kegiatan Siswa. Selanjutnya, untuk melengkapi produk 
tersebut juga disusun silabus, kunci jawaban lembar kegiatan siswa, dan tes hasil belajar (tes prestasi belajar dan angket self-esteem). Perangkat pembelajaran berupa RPP dapat membantu guru untuk menyelenggarakan kegiatan pembelajaran yang mampu memfasilitasi kecerdasan majemuk siswa. Perangkat pembelajaran berupa buku menjadi sumber belajar dan melengkapi lembar kegiatan siswa yang secara satu kesatuan bertujuan untuk memfasilitasi kecerdasan majemuk siswa.

Produk pengembangan berupa perangkat pembelajaran dalam penelitian ini telah dinilai oleh dosen ahli dan guru matematika. Pertama, penilaian RPP yang dilakukan mendapatkan kesimpulan rata-rata sebesar 4,33 dan memenuhi klasifikasi sangat baik. Berdasarkan hasil penilaian tersebut dapat disimpulkan bahwa RPP layak untuk digunakan dalam pembelajaran matematika dan telah dikembangkan berdasarkan prosedur pengembangan RPP yang sesuai. RPP dikatakan layak berdasarkan beberapa aspek yaitu kesesuaian pembelajaran berbasis kecerdasan majemuk, kelayakan isi, kelayakan kebahasaan, dan kelayakan penyajian.

Kedua, buku geometri yang dinilai berdasarkan dua hal yaitu penilaian buku geometri dari segi materi sebagai bahan ajar dan penilaian tampilan buku geometri. Hasil penilaian buku dari segi materi sebagai bahan ajar memperoleh rata-rata 4,30 dan memenuhi klasifikasi sangat baik. Berdasarkan hal tersebut dapat disimpulkan bahwa kualitas dari buku yang dikembangkan telah memenuhi kriteria sebagai bahan ajar yang dapat digunakan dalam pembelajaran. Selanjutnya, berdasarkan penilaian tampilan diperoleh rata-rata penilaian 4,64 dengan kriteria sangat baik. Hal ini menunjukkan bahwa buku tersebut layak sebagai bahan ajar yang berupa media cetak.

Ketiga, penilaian pada lembar kegiatan siswa memperoleh penilaian dengan rata-rata 4,44 dengan klasifikasi sangat baik. Oleh karena itu, lembar kegiatan siswa yang dikembangkan telah memenuhi aspek kesesuaian pembelajaran berbasis kecerdasan majemuk, kesesuaian syarat didaktik, kesesuaian syarat konstruksi, kesesuaian syarat teknis, kelayakan isi, kebahasaan, dan kelayakan penyajian. Selain itu penilaian tampilan yang mencakup aspek esederhanaan, keterpaduan, penekanan, keseimbangan, dan warna diperoleh rata-rata 4,51 dengan klasifikasi sangat baik. Berdasarkan penilaian secara keseluruhan tersebut maka dapat disimpulkan lembar kegiatan siswa telah memenuhi kriteria untuk menjadi bahan ajar yang dapat digunakan dalam pembelajaran matematika di sekolah.

Keempat, penilaian instrumen penilaian yang mencakup tes prestasi belajar angket self-esteem. Instrumen penilaian direvisi sesuai masukan dari ahli. Hal-hal yang perlu direvisi antara lain redaksi, kesalahan penulisan, kesesuaian kisi-kisi dengan soal, dan kunci jawaban. Instrumen penilaian yang telah direvisi berdasarkan hasil penilaian dan masukan dari validator, dinyatakan telah memenuhi aspek kevalidan. Hal ini juga sesuai dengan pendapat Fitriyani dan Sugiman (2014, p.14) yang menyatakan bahwa suatu produk dikatakan valid, karena telah melalui proses validasi ahli sampai diperoleh hasil yang valid.

Selanjutnya, uji coba produk diawali dengan uji coba terbatas. Uji coba terbatas bertujuan untuk mendapat masukan dari siswa mengenai buku dan lembar kegiatan siswa yang dikembangkan. Selain itu, uji coba terbatas juga dilakukan pada angket self-esteem dan tes prestasi belajar. Berdasarkan uji coba terbatas dilakukan perbaikanperbaikan yang diperlukan untuk meningkatkan kualitas dari produk pengembangan. Perbaikan-perbaikan tersebut misalnya redaksi, kalimat pengantar aktivitas yang kurang efektif, dan kesalahan penulisan.

Uji coba selanjutnya adalah uji coba dalam pembelajaran matematika di kelas. Peneliti mengamati penggunaan produk selama pembelajaran, diketahui bahwa produk pengembangan dapat memfasilitasi siswa dalam berbagai aktivitas yang memfasilitasi kecerdasan majemuk. Ketika pembelajaran di kelas siswa terlihat aktif dan semangat dalam belajar. Berdasarkan hasil wawancara, siswa menyatakan bahwa merasa terbantu dengan adanya buku dan lembar kegiatan siswa yang digunakan dalam pembelajaran. Selain itu, keberagaman aktivitas dalam belajar seperti bernyanyi dan bermain membuat siswa merasa termotivasi. Melalui pemberian reward dan refleksi siswa, siswa diberi kesempatan untuk belajar menghargai diri.

Secara keseluruhan pelaksanaan pembelajaran berlangsung dengan lancar dan sesuai harapan. Pelaksanaan uji coba diakhiri dengan penilaian yang merupakan aspek dari kualitas keefektifan, hasil penilaian dapat dilihat pada Tabel 5. Hasil tes prestasi belajar untuk kelas A dan B berturut-turut diperoleh rata-rata 82,26 (sangat baik) dan 80,90 (sangat baik). Ketuntasan belajar siswa untuk kelas A dan B berturut-turut mencapai 80,76\% dan 83,33\% dengan rata-rata $82,05 \%$. Berdasarkan klasifikasi penilaian kualitas keefektifan ketuntasan belajar yang menunjukkan $\bar{x}>80 \%$ diklasifikan sangat efektif. Selanjutnya, berdasarkan ketuntasan belajar siswa untuk tes prestasi belajar menunjukkan bahwa kualitas produk hasil pengembangan dikatakan sangat efektif. Hal ini sesuai dengan pendapat Kemp yang menyatakan paling tidak $80 \%$ ketuntasan belajar siswa dapat dicapai agar pembelajaran dapat dikatakan sangat efektif (Kemp, 1994, p.289). Secara keseluruhan prestasi belajar siswa sudah baik, hal ini 
bisa dilihat dari rata-rata nilai siswa untuk tes prestasi belajar dengan rata-rata untuk kelas A 82,69 dan kelas B 80,90 berturut-turut masuk ke klasifikasi sangat baik dan sangat baik.

Tabel 5. Hasil Prestasi Belajar Siswa

\begin{tabular}{lll}
\hline Deskripsi & Kelas A & Kelas B \\
\hline Rata-Rata & 82,26 & 80,90 \\
Nilai Maksimal & 100 & 100 \\
Nilai Minimal & 50 & 50 \\
Persentase Ketuntasan (\%) & 80,76 & 83,33 \\
\hline
\end{tabular}

Pembelajaran menggunakan perangkat pembelajaran berbasis kecerdasan majemuk terbukti memberikan kontribusi positif bagi prestasi belajar siswa. Hal ini juga sesuai dengan penelitian yang dilakukan oleh Bilgin (2005) melalui pembelajaran berbasis kecerdasan majemuk siswa mencapai prestasi yang lebih tinggi dari pada yang mendapatkan pembelajaran biasa. Akan tetapi, masih terdapat siswa yang masih belum mencapai ketuntasan belajar yang diharapkan. Berdasarkan tes prestasi belajar terdapat sembilan siswa yang tidak tuntas. Hal tersebut tentunya dipengaruhi oleh faktor-faktor tertentu yang membuat terdapat beberapa siswa tidak mencapai ketuntasan belajar. Menurut peneliti, hal ini terjadi karena masih ada siswa yang belum terbiasa untuk melakukan kegiatan pembelajaran yang dilakukan, dan kurang serius dalam belajar. Berdasarkan tanya jawab dengan guru, memang pada kenyataannya beberapa siswa cenderung mengesampingkan pembelajaran, sehingga kurang serius dalam belajar.

Selanjutnya, self-esteem siswa juga menjadi salah satu penentu kualitas keefektifan produk pengembangan yang dapat dilihat pada Tabel 6 dan Tabel 7. Secara keseluruhan, memang self-esteem siswa kelas A dan B sudah baik hal ini dapat dilihat dari rata-rata self-esteem yang mencapai klasifikasi sedang dan tinggi. Akan tetapi, masih terdapat empat siswa yang masuk ke klasifikasi rendah dan dua puluh enam siswa masuk ke klasifikasi sedang. Namun, setelah pembelajaran menggunakan perangkat yang dikembangkan dalam penelitian ini memberikan kontribusi positif.

Tabel 6. Hasil Self-esteem Siswa Kelas A

\begin{tabular}{lllll}
\hline \multirow{2}{*}{ Klasifikasi } & \multicolumn{3}{l}{ Sebelum } & \multicolumn{2}{l}{ Setelah } \\
\cline { 2 - 5 } & $\mathrm{N}$ & $\%$ & $\mathrm{~N}$ & $\%$ \\
\hline Sangat tinggi & 2 & 7,7 & 2 & 8,3 \\
Tinggi & 7 & 26,9 & 9 & 37,5 \\
Sedang & 13 & 50 & 13 & 54,2 \\
Rendah & 4 & 15,4 & 0 & 0 \\
Sangat rendah & 0 & 0 & 0 & 0 \\
Rata-rata skor & 117,25 & 136,58 \\
Klasifikasi & \multicolumn{2}{l}{ Sedang } & Tinggi \\
\hline
\end{tabular}

Tabel 7. Hasil Self-esteem Siswa Kelas B

\begin{tabular}{lllll}
\hline \multirow{2}{*}{ Klasifikasi } & \multicolumn{2}{l}{ Sebelum } & \multicolumn{2}{l}{ Setelah } \\
\cline { 2 - 5 } & $\mathrm{N}$ & $\%$ & $\mathrm{~N}$ & $\%$ \\
\hline Sangat tinggi & 2 & 8,3 & 7 & 29,2 \\
Tinggi & 9 & 37,5 & 17 & 70,8 \\
Sedang & 13 & 54,2 & 0 & 0 \\
Rendah & 0 & 0 & 0 & 0 \\
Sangat rendah & 0 & 0 & 0 & 0 \\
Rata-rata skor & 123 & 139,67 \\
Klasifikasi & Tinggi & \multicolumn{2}{c}{ Tinggi } \\
\hline
\end{tabular}

Rata-rata secara keseluruhan sebelum pembelajaran untuk kelas A mencapai 117,25 dengan klasifikasi sedang dan setelah pembelajaran mencapai 136,58 mencapai klasifikasi tinggi. Rata-rata secara keseluruhan sebelum 
pembelajaran untuk kelas B mencapai 123 dengan klasifikasi tinggi dan setelah pembelajaran mencapai 139,67 mencapai klasifikasi tinggi, sehingga berdasarkan klasifikasi self-esteem maka perangkat pembelajaran dapat dikatakan efektif. Berdasarkan hasil tes prestasi belajar self-esteem siswa dalam pembelajaran, perangkat pembelajaran geometri berbasis kecerdasan majemuk yang dikembangkan dalam penelitian ini memenuhi aspek kefektifan. Berdasarkan hasil tersebut dapat disimpulkan bahwa perangkat pembelajaran memberikan kontribusi positif bagi prestasi belajar dan self-esteem siswa.

Kontribusi positif ini ditunjukkan setelah pembelajaran tidak ada lagi siswa yang masuk ke klasifikasi rendah dan hanya satu siswa yang masuk klasifikasi sedang. Hal ini juga sesuai dengan sebuah studi kasus di Gillots School, Henley-on-Thames, Inggris dimana diterapkan pembelajaran berbasis kecerdasan majemuk. Seorang guru bernama Jo lles menyatakan bahwa melalui pembelajaran berbasis kecerdasan majemuk dapat meningkatkan selfesteem (Fleetham, 2006, p.119). Berdasarkan wawancara siswa kegiatan pembelajaran berbasis kecerdasan majemuk memahami pelajaran memberikan pengaruh positif bagi self-esteem siswa. Siswa yang awalnya tidak bersemangat dalam belajar menjadi lebih semangat dan menikmati pembelajaran matematika. Hal ini dikarenakan kegiatan pembelajaran yang bervariasi dan memfasilitasi kebutuhan siswa.

Kontribusi yang positif ini juga ditunjukkan dengan respon siswa dan respon guru yang berhubungan dengan kualitas kepraktisan. Respon siswa setelah pembelajaran diketahui sekitar $68 \%$ siswa memberikan respon sangat praktis, sekitar $24 \%$ siswa memberikan respon praktis, sekitar $8 \%$ siswa memberikan respon cukup praktis, dan tidak ada siswa atau $0 \%$ siswa memberikan respon tidak praktis dan sangat tidak praktis. Dimana rata-rata respon siswa sebesar 4,175 dengan klasifikasi praktis. Berdasarkan respon siswa tersebut siswa memberikan respon yang positif pada perangkat pembelajaran yang dikembangkan. Sedangkan, untuk respon guru memperoleh klasifikasi sangat praktis dengan rata-rata 4,625.

Selanjutnya, dari segi keterlaksanaan pembelajaran untuk kelas A ketercapaian sebesar 96,82\% dan kelas B sebesar $97,61 \%$. Berdasarkan hal tersebut kualitas perangkat pembelajaran dikatakan praktis karena keterlaksanaan pembelajaran telah masuk ke kriteria sangat baik. Oleh karena itu,berdasarkan hasil respon siswa, respon guru, dan observasi keterlaksanaan pembelajaran, perangkat pembelajaran geometri berbasis kecerdasan majemuk uang dikembangkan dalam penelitian ini memenuhi aspek kepraktisan. Heming (2008) dalam penelitiannya juga menemukan bahwa teori kecerdasan majemuk dapat diaplikasikan secara praktis dalam pembelajaran.

\section{SIMPULAN}

Pengembangan perangkat pembelajaran dalam penelitian ini menggunakan model Plomp yang mencakup tiga tahapan. Tahap pertama, penelitian awal mencakup analisis kebutuhan yaitu analisis materi dan analisis situasi. Tahap kedua, pengembangan yang mencakup desain produk dan pembuatan produk. Pada tahapan ini diperoleh produk awal yang berupa rencana pelaksanaan pembelajaran, buku dan lembar kegiatan siswa. Tahap ketiga, evaluasi yang meliputi proses penilaian (validasi) dan uji coba. Proses validasi merupakan proses penilaian oleh para ahli yaitu dua dosen ahli dan satu guru matematika. Berdasarkan penilaian tersebut diperoleh saran dan masukan untuk dapat menyempurnakan produk yang dikembangkan. Selanjutnya dilakukan proses uji coba dan diperoleh produk dari pengembangan berupa perangkat pembelajaran berberbasis kecerdasan majemuk berorientasi pada prestasi belajar dan self-esteem siswa SMP kelas VIII semester 2.

Kualitas produk hasil pengembangan dalam penelitian ini ditentukan berdasarkan tiga aspek yaitu aspek kevalidan, aspek keefektifan, dan aspek kepraktisan. Berdasarkan hasil penelitian dan pembahasan, dapat disimpulkan bahwa perangkat pembelajaran geometri berbasis kecerdasan majemuk siswa memenuhi kualitas valid, efektif, dan praktis. Oleh karena itu, perangkat pembelajaran yang dikembangkan layak untuk dapat digunakan sebagai salah satu perangkat pembelajaran matematika. Beberapa saran yang dapat peneliti sampaikan berdasarkan hasil penelitian ini, yaitu (1) produk dari pengembangan ini hendaknya dapat digunakan lebih lanjut dalam pembelajaran matematika; (2) perlu pengembangan materi secara keseluruhan yang lebih mendetail sehingga meningkatkan kualitas dari perangkat pembelajaran; (3) perlu adanya tindak lanjut dari peneliti lain, karena perangkat pembelajaran yang dihasilkan dari penelitian ini masih kurang sempurna.

\section{DAFTAR PUSTAKA}

Arends, R. I. (2012). Learning to teach (9th ed.). New York, NY: Mc. Graw Hill.

Armstrong, T. (2009). Multiple intelligences in the classroom. Alexandria, VA: ASCD. 
Azwar, S. (2014). Penyusunan skala psikologi. Yogyakarta: Pustaka Pelajar.

Bilgin, E. K. (2005). The effect of multiple intelligences based instruction on ninth graders chemistry achievement and attitudes toward chemistry (Master's thesis, Middle East Technical University, Ankara). Retrieved from https://etd.lib.metu.edu.tr/upload/12607413/index.pdf

Brownlie, F., Renihan, F., Ladyman, S., Sumanik, G., MacRae, J., \& Wickstorm, R. (2003). Enhanching learning: report of the student achievement task force. British Columbia, Canada: Ministry of Education.

Brown, J. D., Dutton, K. A., \& Cook, K. E. (2001). From the top down: Self-esteem and self-evaluation. Cognition and Emotion, 15(5), 615-631. doi: http://dx.doi.org/10.1080/02699930143000004

BSNP. (2012). Panduan pemanfaatan hasil UN tahun pelajaran 2011/2012 untuk perbaikan mutu pendidikan. Jakarta: Badan Penelitian dan Pengembangan Pendidikan.

BSNP. (2013). Panduan pemanfaatan hasil UN tahun pelajaran 2012/2013 untuk perbaikan mutu pendidikan. Jakarta: Badan Penelitian dan Pengembangan Pendidikan.

Campbell, L., \& Campbell, B. (1999). Multiple intelligences and student achievement. Alexandria, VA: Association for Supervision and Curriculum Development.

Dehyadegary, E., Divsalar, K., Shahsavari, F. P., Nekouei, S., \& Sadr, A.J . (2012). Academic engagement as a mediator in relationships between emotional intelligence and academic achievement among adolescents in KermanIran. Journal of American Science, 8(9), 823-832. doi: https://dx.doi.org/10.7537/marsjas080912.113

Fitriyani, W., \& Sugiman, S. (2014). Pengembangan perangkat pembelajaran teorema pythagoras dengan pendekatan ideal berbantuan geogebra. Jurnal Riset Pendidikan Matematika, 1(2), 269-284. doi: https://doi.org/10.21831/jrpm.v1i2.2681

Fleetham, M. (2006). Multiple intelligences in practice: Enhancing self-esteem and learning in the classroom. Stafford, UK: The Continum International Publishing.

Gravemeijer, K. (2004). Local instruction theories as means of support for teachers in reform mathematics education. Mathematical Thinking and Learning, 6(2), 105-108. Retrieved from https://www.tandfonline.com/doi/abs/10.1207/s15327833mt10602_3

Heming, L., A. (2008). Multiple intelligences in the classroom (Master's thesis, Western Kentucky University, Kentucky). Retrieved from https://core.ac.uk/download/pdf/43646744.pdf

Hewitt, D. (2008). Understanding effective learning: strategies for the classroom. London, UK: McGraw-Hill, Open University Press.

Ignacio, N. G., Nieto, L. J. B., \& Barona, E. G. (2006). The affective domain in mathematics learning. International Electronic Journal of Mathematics Education, 1(1), 16-32. Retrieved from https://www.iejme.com/article/theaffective-domain-in-mathematics-learning

Kemp, J. E., Morrison, G. R., \& Ross, S. M. (1994). Designing effective instruction. New York, NY: Merrill Publishing.

Leonard, L., \& Supardi, S. (2010). Pengaruh konsep diri, sikap siswa pada matematika, dan kecemasan siswa terhadap hasil belajar matematika. Cakrawala Pendidikan, XXIX(3),341-352. doi: https://doi.org/10.21831/cp.v3i3.362

Lovat, T., Dally, K., Clement, N., \& Toomey, R. (2011). Value pedagogy and student achievement: Contemporary research evidence. New York, NY: Springer Science+Business Media.

McCombs, B. L. \& Pope, J. E. (1994). Motivating to reach students. Washington, DC: American Psychological Association.

McKinley, J. (2010). Raising black students' achievement through culturally responsive teaching. Alexandria, VA: ASCD.

Muijs, D., \& Reynolds, D. (2011). Effective teaching: Evidence and practice. London, UK: Sage. 
Mullis, I. V. S., Martin, M. O., \& Foy, P. (2008). TIMSS 2007 international mathematics reports. Boston, MA: TIMSS \& PIRLS International Study Center.

Mullis, I. V. S., Martin, M. O., Foy, P., \& Arora, A. (2012). TIMSS 2011 international results in mathematics. Boston, MA: TIMSS \& PIRLS International Study Center.

Muslimin, Z. I. (2012). Prestasi belajar mahasiswa ditinjau dari jalur penerimaan mahasiswa baru, asal sekolah, dan skor tes potensi akademik. Jurnal Penelitian Psikologi, 3(1), 381-393.

NCTM. (2000). Principles and standards for school mathematics. Virginia, VA: Author.

Nieveen, N. (1999). Prototyping to reach product quality. In T. Plomp, N. Nieveen, K. Gustafson, R. M. Branch, \& J. van den Akker (eds.), Design approaches and tools in education and training (pp. 125-136). London, UK: Kluwer Academic Publisher

Nitko, A. J., \& Brookhart, S. M. (2011). Educational asessment of students. Prentice Hall, NJ: Pearson.

Phye, G. D. (1997). Handbook classroom assesment: Learninng, achievement, and adjustment. New York, NY: Academic Press.

Plomp, T. (2013). Educational design research. Eschende: Netherlands Institute for Curriculum Development (SLO).

Popham, W. J. (1995). Classroom assessment: What teachers need to know. London, UK: Allyn and Bacon.

Reynolds, W. M., \& Miller, G. E. (2003). Handbook of psychology. Hoboken, NJ: John Wiley \& Sons.

Robert, L. \& Chair, L. (2009). Student learning, students achievement: How do teachers measure up? Arlington, VA: National Board for Profesional Teaching Standards (NBPTS).

Santrock, J. W. (2011). Educational psychology. New York, NY: Mc Graw-Hill.

Slavin, R. E. (2006). Education psychology: theory and practice. New York, NY: Pearson Education International.

Widoyoko, E. P. (2012). Teknik penyusunan instrumen penelitian. Yogyakarta: Pustaka Pelajar.

Widjajanti, D. J. (2012). Teori kecerdasan majemuk: Apa dan bagaimana mengaplikasikannya dalam pembelajaran matematika. Prosiding Seminar Nasional Penelitian, Pendidikan dan Penerapan MIPA, Universitas Negeri Yogyakarta. Retrieved from https://bit.ly/2m660Mi

Winkel, W. S. (2004). Psikologi pengajaran. Yogyakarta: Media Abadi. 